\title{
Hybrid materials through linkage of chalcogenide tetrahedral clusters
}

Article

Accepted Version

Vaqueiro, P. (2010) Hybrid materials through linkage of chalcogenide tetrahedral clusters. Dalton Transactions, 39 (26). pp. 5965-5972. ISSN 1364-5447 doi:

https://doi.org/10.1039/C000130A Available at https://centaur.reading.ac.uk/40408/

It is advisable to refer to the publisher's version if you intend to cite from the work. See Guidance on citing.

To link to this article DOI: http://dx.doi.org/10.1039/C000130A

Publisher: Royal Society of Chemistry

All outputs in CentAUR are protected by Intellectual Property Rights law, including copyright law. Copyright and IPR is retained by the creators or other copyright holders. Terms and conditions for use of this material are defined in the End User Agreement.

\section{www.reading.ac.uk/centaur}

\section{CentAUR}

Central Archive at the University of Reading

Reading's research outputs online 


\title{
Hybrid materials through linkage of chalcogenide tetrahedral clusters
}

\author{
Paz Vaqueiro* \\ Department of Chemistry, Heriot-Watt University, Edinburgh EH14 4AS, UK
}

*Author for correspondence:

Dr P. Vaqueiro

Department of Chemistry

Heriot-Watt University

Edinburgh EH14 4AS

UK

Fax: +44 (0)131 4513180

E-mail: chepv@hw.ac.uk 


\begin{abstract}
Tetrahedral chalcogenide clusters, with their well-defined molecular structures and interesting properties, are attractive building blocks for hybrid materials, in which porosity may be integrated with electronic or optical properties. Linkage of tetrahedral clusters often occurs through bridging chalcogenolate ligands, and results in extended structures of inorganic connectivity. However, linkage of tetrahedral clusters via organic ligands is also possible and a number of coordination polymers have already been reported. Recent advances on the synthesis and crystal structures of extended hybrid structures based on tetrahedral clusters are described here.
\end{abstract}




\section{Introduction}

Hybrid materials, constructed from covalently bonded organic and inorganic moieties, have developed into an important new class of solid-state materials over the last two decades. ${ }^{1}$ Their synthesis involves the combination of different organic and inorganic moieties and provides an unprecedented capacity to yield materials with novel properties, arising from synergistic interactions between dissimilar components. ${ }^{2}$ The use of well defined metal clusters as building blocks is a promising approach for the preparation of hybrid materials. Extended hybrid solids based on inorganic clusters instead of individual metal centres can be expected to have an expanded structure which, for three-dimensional solids, could result in highly porous materials, containing pores in either the micro- or mesoporous range. In addition, the introduction of an organic component within the structure provides control over the dimensions of the pores through modification of the length and the shape of the organic chains, and also enables the functionalization of the organic linker depending on the desired applications. By modifying the connectivities of both the organic ligands and the inorganic clusters, access to a wide variety of topologies and structures should be possible. In addition, the optical and electronic properties of inorganic nanoclusters, which can be considered as intermediate between those of mononuclear species and bulk materials, may be modified by controlling the cluster size, composition and interactions. ${ }^{3}$

Tetrahedral chalcogenide clusters, with their well-defined molecular structures and their interesting optical and electrical properties, ${ }^{4}$ are attractive building blocks for hybrid materials. Traditionally, a coordination chemistry approach has been used for the preparation of tetrahedral chalcogenide clusters. ${ }^{5,6}$ More recently, solvothermal synthesis has been exploited for the preparation of hybrid materials containing 
tetrahedral chalcogenide clusters. This has resulted in the identification of new clusters, as well as novel hybrid extended structures. After a brief overview of the existing families of tetrahedral clusters, here we will focus on the use of such units as building blocks for the assembly of hybrid extended structures.

\section{Tetrahedral clusters}

Several families of tetrahedral clusters, which include supertetrahedral, pentasupertetetrahedral and capped clusters, are known. They are formed by chalcogenides and chalcogenolates of main group (Ga, In, Ge, Sn) and transitionmetal elements ( $\mathrm{Fe}, \mathrm{Co}, \mathrm{Zn}, \mathrm{Cd}, \mathrm{Hg})$. Inorganic open-framework chalcogenides containing tetrahedral clusters have been recently reviewed, ${ }^{7}$ while Dance and Fisher produced an extensive review on the synthesis and geometry of chalcogenide and thiolate clusters, including tetrahedral clusters. ${ }^{5}$

\subsection{Supertetrahedral clusters}

Supertetrahedral clusters are tetrahedrally shaped fragments of the cubic ZnS-type lattice, and are generally denoted as Tn, where the index $n$ indicates the number of individual tetrahedron along each edge (Figure 1). A T1 unit is a single tetrahedron, whilst the adamantane cluster, which contains four corner-linked tetrahedra, is a T2 unit. T3, T4 and T5 chalcogenide clusters, containing ten, twenty and thirty five corner-linked tetrahedra respectively, have also been reported. $^{7} \mathrm{~T} 2$ and T3 supertetrahedral clusters are often found in chalcogenides of groups 13 and 14. For example, isolated T2 supertetrahedral clusters $\left[\mathrm{Ga}_{4} \mathrm{~S}_{10}\right]^{8-},\left[\operatorname{In}_{4} \mathrm{Q}_{10}\right]^{8-},\left[\mathrm{Ge}_{4} \mathrm{Q}_{10}\right]^{4-}$ and $\left[\mathrm{Sn}_{4} \mathrm{Q}_{10}\right]^{4-}(\mathrm{Q}=\mathrm{S}, \mathrm{Se})$ can be produced from aqueous solutions. ${ }^{8,9}$ A number of boron sulphides, including $\mathrm{B}_{2} \mathrm{~S}_{3}$, also contain $\mathrm{T} 2$ clusters as building blocks. ${ }^{9}$ It has been 
found that for the preparation of larger supertetrahedral clusters, cations with lower valences are required. ${ }^{10}$ The $\mathrm{Q}^{2-}$ anions at the center of these large clusters will be four-coordinated, and low-valence cations are necessary to maintain the local charge neutrality and prevent excessive positive charge around those tetrahedral $\mathrm{Q}^{2-}$ sites, in accord with Pauling's electrostatic valence rule.

In addition to the wholly inorganic supertetrahedral clusters, chalcogenolate ligands can be used for the preparation of hybrid supertetrahedral clusters in which $\mathrm{Q}^{2-}$ anions at both the faces and the vertexes of the cluster have been replaced by chalcogenolate anions. These clusters therefore consist of an inorganic core surrounded by a chalcogenolate shell. Known T2 chalcogenolate clusters include $\left[\mathrm{M}_{4}(\mathrm{SPh})_{10}\right]^{2-}(\mathrm{M}=$ Fe, Co) (Figure 2(a)), ${ }^{11}$ whilst examples of T3 clusters are $\left[\mathrm{M}_{10} \mathrm{Q}_{4}(\mathrm{SPh})_{16}\right]^{4-}(\mathrm{M}=\mathrm{Zn}$, $\mathrm{Cd}, \mathrm{Q}=\mathrm{S}, \mathrm{Se}),{ }^{12}\left[\mathrm{Zn}_{10} \mathrm{~S}_{4}(\mathrm{SEt})_{12} \mathrm{~L}_{4}\right](\mathrm{L}=3,5 \text {-dimethylpyridine, pyridine })^{13}$ and $\left[\mathrm{Cd}_{10} \mathrm{~S}_{4} \mathrm{I}_{4}(\mathrm{SPh})_{12}\right]^{4-14}$ A large $\mathrm{T} 5$ unit, with a tetrahedral hole in the centre, $\left[\mathrm{Hg}_{34} \mathrm{Te}_{16}(\mathrm{SePh})_{36}\left(\mathrm{PPh} n \mathrm{Pr}_{2}\right)_{4}\right]$, has also been described. ${ }^{15}$ As evidenced by these examples, halide, amine or phosphine ligands can also be incorporated into the clusters, where they generally occupy the vertex positions. Introduction of halide ligands into the clusters results in red shifts and significant enhancements of the luminescence. $^{14}$

In recent years, other types of hybrid supertetrahedral clusters, which do not contain chalcogenolate ligands, have been reported. These include the T2 cluster $\left[\mathrm{Ga}_{4} \mathrm{~S}_{6}\left(\mathrm{NC}_{9} \mathrm{H}_{15} \mathrm{~N}_{2}\right)_{4}\right],{ }^{16}$ and the family of $\mathrm{T} 3$ clusters $\left[\mathrm{Ga}_{10} \mathrm{~S}_{16} \mathrm{~L}_{4}\right]^{2-}(\mathrm{L}=3,5-$ dimethylpyridine, 4-methylpyridine), in which the $\mathrm{S}^{2-}$ anions at the vertexes of the cluster have been replaced by aromatic amines (Figure 2(b)). ${ }^{17}$ Charge effects can be used to justify the absence of chalcogenolate ligands in these clusters: the increase of the formal charge of $\mathrm{Ga}^{3+}$ when compared to $\mathrm{Cd}^{2+}$ or $\mathrm{Zn}^{2+}$ leads to the replacement of 
$\mathrm{RS}^{-}$ligands by $\mathrm{S}^{2-}$ ions on the faces of the cluster. A T3 supertetrahedral cluster in which a $\left[\mathrm{Sn}_{4} \mathrm{Ga}_{4} \mathrm{Zn}_{2} \mathrm{Se}_{20}\right]^{8-}$ core is covalently terminated by four [(TEPA)Mn $]^{2+}$ $($ TEPA $=$ tetraethylenepentamine $)$ metal complexes at the vertexes, has also been recently described. ${ }^{18}$

Some examples of super-supertetrahedral clusters are also known. The notation Tp,q, which indicates a $\mathrm{T} q$ supertetrahedron of $\mathrm{T} p$ supertetrahedra, is used to describe them. For example, $\left[\mathrm{Cd}_{16} \operatorname{In}_{64} \mathrm{~S}_{134}\right]^{44-}$ is a T2 cluster in which each tetrahedra has been replaced by a T4 supertetrahedron, and is therefore a T4,2 cluster, ${ }^{19}$ whilst $\left[\mathrm{Cd}_{16}(\mathrm{SePh})_{32}\left(\mathrm{PPh}_{3}\right)_{2}\right]$ is a T2,2 cluster (Figure 2(c)).$^{20}$

\subsection{Pentasupertetrahedral clusters}

Pentasupertetrahedral clusters, denoted as $\mathrm{Pn}$, can be formed by coupling four $\mathrm{Tn}$ supertetrahedral clusters onto the faces of an antisupertetrahedral cluster of the same order (Figure 3). The central antisupertetrahedral cluster is a supertetrahedral cluster in which the positions of cations and anions have been exchanged. P1 and P2 clusters are found as building blocks of a number of chalcogenide-based open frameworks. ${ }^{21}$ Materials containing ionic pentasupertetrahedral clusters have also been described. Examples include the ternary P1 cluster, $\left[\mathrm{Co}_{4}\left(\mu_{4}-\mathrm{Se}\right)\left(\mathrm{SnSe}_{4}\right)_{4}\right]^{10-}$, which consists of an anti $\mathrm{T} 1\left[\mathrm{Co}_{4} \mathrm{Se}\right]$ unit capped by four $\mathrm{T} 1\left[\mathrm{SnSe}_{4}\right]$ units. $^{22} \mathrm{~A}$ number of cadmiumcontaining P1 clusters, $\left[\mathrm{Cd}_{8} \mathrm{Q}\left(\mathrm{Q}^{\prime} \mathrm{Ph}\right)_{16}\right]^{2-}\left(\mathrm{Q}, \mathrm{Q}^{\prime}=\mathrm{S}, \mathrm{Se}, \mathrm{Te}\right),{ }^{23}$ have been prepared by crystallisation from solution, but there are also reports of P1 clusters, such as $\left[\mathrm{Zn}_{8} \mathrm{~S}\left(\mathrm{SC}_{6} \mathrm{H}_{5}\right)_{14} \mathrm{~L}_{2}\right] \quad(\mathrm{L}=$ 3-aminopyridine, 4-(dimethylamino)pyridine, 4methylpyridine) or $\left[\mathrm{Cd}_{8} \mathrm{~S}(\mathrm{SPh})_{16}\right]^{2-}$, prepared under solvothermal conditions. ${ }^{24,25}$ Ionpair charge-transfer salts, containing pentasupertetrahedral or supertetrahedral anions and methylviologen cations, have been recently reported. ${ }^{24}$ These materials exhibit 
significant red-shifts in their UV-Vis spectra, and therefore provide a potential route to modify the optical properties of cluster-based hybrid frameworks.

\subsection{Capped supertetrahedral clusters}

Capped clusters, which are generally denoted as $\mathrm{Cn}$, can be defined as consisting of a core which is a regular fragment of the cubic ZnS-type lattice, together with four corner barrelanoid cages possessing the characteristics of the hexagonal wurtzite-type lattice (Figure 4). Examples of $\mathrm{C} 1$ clusters, including $\left[\mathrm{Cd}_{17} \mathrm{~S}_{4}(\mathrm{SPh})_{28}\right]^{2-},{ }^{26}$ and $\mathrm{C} 2$ clusters, such as $\left[\mathrm{Cd}_{32} \mathrm{~S}_{14}(\mathrm{SPh})_{36}(\mathrm{DMF})_{4}\right],{ }^{27}\left[\mathrm{Cd}_{32} \mathrm{~S}_{14}\left(\mathrm{SCH}_{2} \mathrm{CH}(\mathrm{OH}) \mathrm{CH}_{3}\right)_{36}\left(\mathrm{H}_{2} \mathrm{O}\right)_{4}\right]^{28}$ and $\left[\mathrm{Mn}_{32} \mathrm{Se}_{14}(\mathrm{SePh})_{36}\left(\mathrm{PnPr}_{3}\right)_{4}\right],{ }^{29}$ have been reported. $\left[\mathrm{Hg}_{32} \mathrm{Se}_{14}(\mathrm{SePh})_{36}\right]$ is an unusual $\mathrm{C} 2$ cluster in which the $\mathrm{Hg}$ atoms at the four vertexes of the cluster adopt an almost trigonal planar coordination, instead of the expected tetrahedral coordination. ${ }^{30}$ The existence of a larger cluster, $\left[\mathrm{Cd}_{54} \mathrm{Te}_{32}\left(\mathrm{SCH}_{2} \mathrm{CH}_{2} \mathrm{OH}\right)_{52}\right]^{8-}$, has been proposed on the basis of EXAFS measurements, but its crystal structure has not been determined. ${ }^{31}$ A series of related clusters are those denoted as $\mathrm{Cn}, \mathrm{m}(\mathrm{m}=1-4)$, which have the same composition than the corresponding $\mathrm{Cn}$ cluster, with $m$ barrelanoid cages at the corners rotated by $60^{\circ}$ from their original position in the Cn cluster. ${ }^{7}$ Examples include the $\mathrm{C} 2,2$ cluster $\left[\mathrm{Cd}_{32} \mathrm{~S}_{14}(\mathrm{SPh})_{40}\right]^{4-}$ and the $\mathrm{C} 3,4$ cluster $\left[\mathrm{Cd}_{54} \mathrm{~S}_{32}(\mathrm{SPh})_{48}\left(\mathrm{H}_{2} \mathrm{O}\right)_{4}\right]^{4-} \cdot{ }^{32}$

\section{Extended structures}

Hybrid materials can be classified into two main categories. Structures that contain extended arrays of inorganic connectivity via $\mathrm{M}-\mathrm{X}-\mathrm{M}$ bonding are described as extended inorganic hybrids. By contrast, in coordination polymers or metal-organic frameworks (MOFs), the extended structures are formed through M-L-M connectivity (where $\mathrm{L}$ is a polyfunctional organic ligand). However, both types of linkages coexist 
in some structures, and therefore structures can be further divided into $\mathrm{I}^{n} \mathrm{O}^{m}$ classes ( $\mathrm{I}$ = inorganic, $\mathrm{O}=$ organic, $n, m=0-3$ ) depending on the dimensionality, $n$ and $m$, of the inorganic and the organic connectivities. ${ }^{33}$ The hybrid extended structures based on tetrahedral chalcogenolate clusters (Table 1) and chalcogenide clusters (Table 2) have been classified according to these categories in the following sections.

\subsection{Extended structures containing chalcogenolate clusters}

\section{(a) Extended inorganic hybrids}

The chalcogenolate ligands at the vertexes of supertetrahedral clusters can act as bridging ligands, $\mu-\mathrm{RQ}^{-}$, resulting in the formation of extended structures. For example, supertetrahedral T2 clusters, $\left[\mathrm{Zn}_{4}(\mathrm{SPh})_{9}(\mathrm{ROH})\right]^{2-}\left(\mathrm{R}=\mathrm{CH}_{3}, \mathrm{C}_{2} \mathrm{H}_{5}, \mathrm{C}_{3} \mathrm{H}_{7}\right.$, $\mathrm{C}_{4} \mathrm{H}_{9}$ ), can be linked by bridging benzenothiolate ligands, to form one-dimensional zig-zag chains (Figure 5). ${ }^{34}$ Similarly, mercury-based T2 clusters can be joined through bridging $\mathrm{PhSe}^{-}$ligands into one-dimensional chains of stoichiometry $\left[\mathrm{Hg}_{4}(\mathrm{SePh})_{7} \mathrm{XPy}\right]_{\mathrm{n}}(\mathrm{X}=\mathrm{Cl}, \mathrm{I}, \mathrm{Br}) .{ }^{35} \mathrm{By}$ contrast, $\left[\mathrm{Cd}(\mathrm{SPh})_{2}\right]$ (and the isostructural $\left.\left[\mathrm{Cd}(\mathrm{SePh})_{2}\right]\right)^{36}$ adopts a three-dimensional structure, in which each $\mathrm{T} 2$ cluster is vertex-linked to other four T2 clusters. ${ }^{37}$ Whilst the crystal structure of $\left[\mathrm{Cd}(\mathrm{SPh})_{2}\right]$ exhibits the $\alpha$-cristobalite topology (Figure 6(a)), other topologies are found with different substituents in the phenyl rings. In particular, the use of 4methylphenylthiolate results in the formation of a $\mathrm{CrB}_{4}$-type framework, in which tetrahedral boron sites are replaced by T2 clusters (Figure $6(\mathrm{~b})$ ). ${ }^{38}$ A two-dimensional structure, with a corrugated honeycomb-like topology, is obtained when using 4bromophenylthiolate, ${ }^{39}$ whilst reactions using 2-methylphenylthiolate do not result in the formation of adamantane-based structures, presumably owing to steric interactions. $^{40}$ 
In order to prepare larger thiolate clusters, a source of sulphur must be incorporated into the reaction. The use of $\mathrm{CS}_{2}$ or thiourea as $\mathrm{S}^{2-}$ sources, either at room temperature or under mild solvothermal conditions, affords a number of chiral frameworks containing P1 clusters, $\left[\mathrm{Cd}_{8} \mathrm{~S}(\mathrm{SPh}-\mathrm{R})_{16}\right]^{2-}\left(\mathrm{R}=3\right.$-methyl, 4-methyl). ${ }^{41}$ The nature and the position of substituents in the phenyl rings have an influence on the crystal structure topology. Whilst materials containing $\left[\mathrm{Cd}_{8} \mathrm{~S}(\mathrm{SPh}-\mathrm{R})_{16}\right]^{2-}(\mathrm{R}=3$-methyl, 4methyl) adopt the $\beta$-quartz topology (Figure 7(a)), P1 clusters containing 3fluorophenylthiolate form a framework with the $\alpha$-quartz topology. ${ }^{42} \mathrm{~A}$ material containing P1 and $\mathrm{C} 1$ clusters, and crystallising in the moganite topology (Figure 7(b)), can also be obtained under solvothermal conditions using 3methylphenylthiolate. ${ }^{41}$ This is the only known example of a framework containing simultaneously clusters from the $\mathrm{Pn}$ and $\mathrm{Cn}$ series, and suggests that the solution chemistry of this system is likely to involve various equilibrium processes between different clusters. Optical measurements indicate that these materials are wide-band semiconductors.

Capped clusters can also form extended structures. For example, linkage of $\mathrm{C} 1$ clusters, $\left[\mathrm{Cd}_{17} \mathrm{~S}_{4}\left(\mathrm{SCH}_{2} \mathrm{CH}_{2} \mathrm{OH}\right)_{28}\right]^{2-}$, through the four capping thiolate ligands at the vertexes of each cluster, results in the formation of a three-dimensional structure, with the double diamond topology. ${ }^{43}$ Cadmium-based $\mathrm{C} 1$ clusters are also the building units of chiral frameworks with the $\beta$ - quartz topology, ${ }^{41}$ and with an unusual $(3,4)$ connected interpenetrating boracite topology, which exhibits interesting photoelectric properties. ${ }^{44}$ The later crystal structure contains alternating 3-connected $\mathrm{C} 1$ clusters, with one terminating vertex, and 4-connected $\mathrm{C} 1$ clusters. Larger $\mathrm{C} 2$ clusters, $\left[\mathrm{Cd}_{32} \mathrm{~S}_{14}(\mathrm{SPh})_{38}\right]^{2-}$, can be joined by their vertexes to form structures with the double diamond topology, using metal-chelate dyes as templates. ${ }^{45}$ The optical properties of 
these materials are sensitive to the nature of the dyes (as well as to the nature of the semiconducting framework).

\section{(b) Coordination polymers}

In addition to the extended structures in which the chalcogenolate clusters are joined together through vertex-sharing of chalcogen atoms, there are a small number of recent reports concerning materials in which the clusters are linked by organic ligands. In most of these coordination polymers, the organic linker is a pyridyl-based ligand. Although the chalcogenolate clusters could achieve a connectivity of four, lower connectivities are often found, and this favours the formation one-dimensional coordination polymers. For example, the crystal structure of $\left[\mathrm{Zn}_{8} \mathrm{~S}(\mathrm{SPh}){ }_{14} \mathrm{~L}_{2}\right](\mathrm{L}=$ 1,2-bis(4-pyridyl)ethylene (DPE), 1,3-bis(4-pyridyl)propane (bpp)) consists of onedimensional zig-zag chains of alternating P1 clusters and dipyridyl moieties (Figure 8(a)). ${ }^{46}$ One-dimensional coordination polymers containing cadmium-based capped clusters $(\mathrm{C} 0, \mathrm{C} 1, \mathrm{C} 2,1$ and $\mathrm{C} 2,2)$ alternating with 1,3-bis(4-pyridyl)propane (bpp) or 4,4'-bipyridine (bipy) have also been reported. ${ }^{47}$ When flexible bpp is used as the bridging ligand, doubly bridged chains can form (Figure 8(b)), whilst the more rigid bipy ligand is found in singly bridged chains. These materials exhibit size-dependent optical properties, as the absorption edge shifts to longer wavelengths with increasing cluster size. The use of the tetrahedral quadridentate linker tetrakis(4pyridyloxymethylene) methane (TPOM), affords a material containing onedimensional chains of alternating $\mathrm{C} 1$ clusters, $\left[\mathrm{Cd}_{17} \mathrm{~S}_{4}(\mathrm{SPh})_{28}\right]^{2-}$, and TPOM (Figure 8(c)). ${ }^{48}$ In this coordination polymer, TPOM has a lower connectivity than expected, as only two of the four available pyridyl groups are used to crosslink the $\mathrm{C} 1$ clusters. By contrast, linkage of P1 clusters, $\left[\mathrm{Cd}_{8} \mathrm{~S}(\mathrm{SPh})_{16}\right]^{2-}$, by TPOM affords a material containing one-dimensional hybrid ribbons (Figure 8(d)), in which all four pyridyl 
groups are involved in the crosslinking of the chalcogenolate clusters. ${ }^{48}$ It has been suggested that the different connectivity of TPOM in these two crystal structures may be related to the cluster size, as it may be sterically unfavourable to arrange four large C1 clusters around a single TPOM ligand. In both structures, each cluster is coordinated to only two TPOM ligands, because further substitution of the thiolates at the vertexes of the cluster by neutral TPOM ligands would result in an overall positive charge.

A small number of two-dimensional coordination polymers have been reported. Feng et al. described two cadmium thiolates in which the building blocks are dimers consisting of two $\mathrm{C} 2,1$ clusters, $\left[\mathrm{Cd}_{32} \mathrm{~S}_{14}(\mathrm{SPh})_{36} \mathrm{~L}_{4}\right]$ (L = bpp, 1,2-bis(4-pyridyl)ethane (BPEA)), doubly bridged by flexible organic ligands. ${ }^{49}$ This doubly bridging linkage between clusters is similar to that found in the hybrid chains shown in Figure 8(b). However, in these layered materials, each dimer is joined, through four additional ligands, to four other dimers (Figure 9). These two-dimensional structures have only been found for large C2,1 clusters, presumably because for smaller clusters such as $\mathrm{C} 1$, substitution of the four thiolates at the vertexes by neutral ligands would result in positively charged clusters, which have not been observed under solvothermal conditions. A different structural motif is found in $\left\{\mathrm{Cd}_{10} \mathrm{Te}_{4}(\mathrm{SPhMe}-4)_{12}(\mathrm{bpp})_{2}\right\}_{\mathrm{n}}$, in which each supertetrahedral T3 cluster is connected through four bpp ligands into a two-dimensional layer, containing square rings, of ca. $21 \times 21 \AA^{50} .^{50}$ The later material has been found to be strongly photoluminescent $\left(\lambda_{\mathrm{em}}=525 \mathrm{~nm}\right)$.

Although other types of ligands could also act as linkers between clusters, this has not been systematically investigated, and few examples have been reported. This includes methyldithiocarbonate, $\mathrm{CH}_{3} \mathrm{OCS}_{2}{ }^{-}$, which crosslinks cadmium-containing $\mathrm{C} 1$ clusters (Figure 10) into a three-dimensional structure with the double diamond topology, ${ }^{51}$ 
and the $\mathrm{CN}^{-}$ligand, found in the three-dimensional structure of $\left[\mathrm{Cd}_{8} \mathrm{~S}(\mathrm{SBu})_{12}(\mathrm{CN})_{2}\right]$, which exhibits an interpenetrating $\mathrm{Cu}_{2} \mathrm{O}$ topology. ${ }^{26}$ Whilst with neutral pyridyl-based ligands only large clusters are four-connected, these examples suggest that anionic ligands may favour the formation of structures containing four-connected clusters.

\subsection{Extended structures containing chalcogenide clusters}

By comparison with the chalcogenolate clusters, there are very few examples of hybrid extended structures based on chalcogenide clusters. It has been recently demonstrated that hybrid clusters of the type $\left[\mathrm{Ga}_{10} \mathrm{~S}_{16} \mathrm{~L}_{4}\right]^{2-}$ can be joined through ditopic ligands into dimeric units $^{52}$ as well as into coordination polymers. Onedimensional zig-zag chains, in which supertetrahedral clusters and organic ligands alternate, can be prepared by using either pyridine or 3,5-dimethylpyridine as solvents and 1,2,-di(4-pyridyl)ethane as a linker (Figure 11(a)). ${ }^{53}$ Linkage of these supertetrahedral clusters into two-dimensional layers, which exhibit a honeycombtype topology, has been achieved by using 1,2-di(4-pyridyl)ethylene as a linker between clusters (Figure 11(b)). ${ }^{53}$ In the later material, the corrugated layers, which have a pore diameter of $c a .30 \AA$, are stacked in a staggered fashion, and this results in a crystal structure which resembles that of grey arsenic. As illustrated in Figure 11, the connectivity of the supertetrahedral $\left[\mathrm{Ga}_{10} \mathrm{~S}_{16} \mathrm{~L}_{4}\right]^{2-}$ clusters in these two extended structures is lower than four. Whilst the reduced connectivity generally found for cadmium-thiolate clusters is attributed to the lack of stability of positively-charged clusters, these $\left[\mathrm{Ga}_{10} \mathrm{~S}_{16} \mathrm{~L}_{4}\right]^{2-}$ clusters remain negatively charged when all four vertexes contain neutral ligands and therefore assembly of structures in which all four vertexes are connected should be feasible. Whilst the two extended structures described here belong to the $\mathrm{I}^{0} \mathrm{O}^{\mathrm{n}}$ classes, and therefore consist of zero-dimensional inorganic units linked via organic moieties, the range of possible structural types could be increased 
by preparing structures in which both inorganic and organic linkages coexist. Indeed the first example of a two-dimensional $\mathrm{I}^{1} \mathrm{O}^{1}$ structure, in which each cluster is four connected, has been reported very recently. ${ }^{54}$ In addition, by replacing ditopic linkers with multitopic linkers, the preparation of extended structures with a wide range of connectivities would also become possible.

An extended inorganic hybrid, containing indium-telluride supertetrahedral clusters, and which exhibits nonlinear optical properties, has been recently reported. $\left\{\left[\operatorname{In}(e n)_{3}\right]\left[\operatorname{In}_{5} \operatorname{Te}_{9}(e n)_{2}\right] \cdot 0.5 e n\right\}_{n}(e n=$ ethylenediamine $)$ can be described as consisting of layers of alternating T2 $\left[\operatorname{In}_{4} \mathrm{Te}_{9}(e n)\right]^{6-}$ and $\mathrm{T} 1\left[\operatorname{InTe} e_{3}(e n)\right]^{3-}$ clusters, linked via three of their vertexes, and separated by $\left[\operatorname{In}(e n)_{3}\right]^{3+}$ complexes and additional en molecules (Figure 12). ${ }^{55}$ In the supertetrahedral clusters found in this material, one of the Te atoms has been replaced by a monodentate en ligand, which acts as a terminal group and does not allow further connectivity of the framework. A similar arrangement of T2 and T1 clusters is found in $\left[\mathrm{Ge}_{3} \mathrm{~S}_{6} \mathrm{Zn}\left(\mathrm{H}_{2} \mathrm{O}\right) \mathrm{S}_{3} \mathrm{Zn}\left(\mathrm{H}_{2} \mathrm{O}\right)\right]\left[\mathrm{Zn}\left(\mathrm{C}_{6} \mathrm{~N}_{4} \mathrm{H}_{18}\right)\left(\mathrm{H}_{2} \mathrm{O}\right)\right]$, in which instead of en, the infinite layers are terminated at the vertexes by covalently bonded water molecules. ${ }^{56}$

\section{Conclusions and outlook}

Significant advances have been made in the synthesis of hybrid materials containing tetrahedral clusters. Extended structures of inorganic connectivity can be generated by crosslinking the clusters through bridging $\mu-\mathrm{RQ}^{-}$chalcogenolate ligands, but in recent years it has been shown that linkage through organic ligands is also possible. The number of known three-dimensional topologies is still small, and in the vast majority of cases, the structures belong to the $\mathrm{I}^{3} \mathrm{O}^{0}$ class. Given the lack of flexibility of the metal-sulfur-metal angle, ${ }^{7}$ it may be necessary to identify new ways of linking the 
clusters in order to obtain new structural types. The incorporation of organic moieties as linkers is a promising route for the generation of novel organic-inorganic architectures, as evidenced by the results described here. However, control over the crystal structures of these coordination polymers is hard to achieve. Optimisation of the packing of the clusters, together with hydrogen bonding and $\pi-\pi$ interactions, are likely to influence the formation of a particular coordination polymer.

Although work to date has been focused on structural aspects, materials with interesting photoluminescent, photoelectric or nonlinear optical properties have already been reported. ${ }^{47,44,55}$ It has also been suggested that materials containing metal chalcogenide clusters behave as arrays of quantum dots, and exhibit size-dependent optical properties. $^{47}$

Efforts should be made to identify suitable templates for the preparation of hybrid cluster-based materials with permanent porosity. This would open new perspectives for the design of a family of multifunctional porous materials in which the traditional ion-exchanging and catalytic features of zeolites can be combined the electronic and optical properties of the chalcogenide clusters, for sensing applications.

\section{References}

1. G. Férey, Chem. Soc Rev., 2008, 37, 191-214; S. Kitagawa, R. Kitaura and S. Noro, Angew. Chem. Int. Ed., 2004, 43, 2334-2375.

2. M. G. Kanatzidis, K. R. Poeppelmeier, Prog. Solid State Chem., 2007, 36, 1-133.

3. H. Weller, Angew. Chem. Int. Ed., 1996, 35, 1079- 1081; J. F. Corrigan, O. Fuhr, D. Fenske, Adv. Mater., 2009, 21, 1867-1871; V. N. Soloviev, A. Eichhöfer, D.

Fenske, U. Banin, J. Am. Chem. Soc., 2001, 123, 2354-2364.

4. N. Hüsing, Angew. Chem. Int. Ed., 2008, 47, 1992-1994; P. Feng, X. Bu, N. Zheng, Acc. Chem. Res., 2005, 38, 293-303.

5. S. Dehnen, M. Melullis, Coord. Chem. Rev., 2007, 251, 1259-1280. 
6. I. Dance and K. Fisher, Prog. Inorg. Chem., 1994, 41, 637-803.

7. X. Bu, N. Zheng, P. Feng, Chem. Eur. J., 2004, 10, 3356-3362.

8. B. Krebs, D. Voelker, K.-O. Stiller, Inorg. Chim. Acta, 1982, 65, L101-L102.

9. B. Krebs, Angew. Chem. Int. Ed., 1983, 22, 113-134.

10. G. Férey, Angew. Chem. Int. Ed., 2003, 42, 2576-2579.

11. K.S. Hagen, D.W. Stephan, R.H. Holm, Inorg. Chem., 1982, 21, 3928-3936; I.G.

Dance, J. Am. Chem. Soc., 1979, 101, 6264-6273.

12. I.G. Dance, A. Choy, M.L. Scudder, J. Am Chem. Soc., 1984, 106, 6285-6295.

13. M.D. Nyman, M.J. Hampden-Smith, E.N. Duesler, Inorg. Chem., 1996, 35, $802-$ 803.

14. R.D. Adams, B. Zhang, C. J. Murphy, L.K. Yeung, Chem. Commun., 1999, 383384.

15. A. Eichhöfer, P. Deglmann, Eur. J. Inorg. Chem., 2004, 349-355.

16. H. Schmidbaur and S. D. Nogai, Z. Anorg. Allg. Chem., 2004, 630, 2218-2225.

17. P. Vaqueiro, M.L. Romero, Chem. Commun., 2007, 3282-3284; P. Vaqueiro, M.L. Romero, Mater. Res. Soc. Symp. Proc. Volume 1148E, Warrendale, PA, 2009, 1148PP10-07.

18. G. Xu, P. Guo, S. Song, H. Zhang, C. Wang, Inorg. Chem., 2009, 48, 4628-4630.

19. H. Li, J. Kim, M. O’Keeffe, O. M. Yaghi, Angew. Chem. Int. Ed., 2003, 42, 18191821.

20. S. Behrens, M. Bettenhausen, A. Eichhöfer, D. Fenske, Angew. Chem. Int. Ed., 1997, 36, 2797-2799.

21. N. Zheng, X. Bu, P. Feng. Angew. Chem. Int. Ed., 2004, 43, 4753-4755; M.J. Manos, R.G. Iyer, E. Quarez, J.H. Liao, M.G. Kanatzidis, Angew.Chem. Int. Ed., 2005, 44, 3552-3555; Q. Zhang, X. Bu, L. Han. P. Feng, Inorg. Chem., 2006, 45, 6684-6687.

22. C. Zimmermann, M. Melullis, S. Dehnen, Angew. Chem. Int. Ed., 2002, 41, 42694272.

23. G.S.H. Lee, K.J. Fisher, D.C. Craig, M.L. Scudder, I.G. Dance, J. Am. Chem. Soc., 1990, 112, 6435-6437.

24. Q. Zhang, T. Wu, X. Bu, T. Tran, P. Feng, Chem. Mater., 2008, 20, 4170-4172.

25. J. Xie, Inorg. Chem., 2008, 47, 5564-5566. 
26. G. S. H. Lee, D.C. Craig, I. Ma, M.L. Scudder, T.D. Bailey, I.G. Dance, J. Am. Chem. Soc., 1988, 110, 4863-4864.

27. N. Herron, J. C. Calabrese, W. E. Farneth and Y. Wang, Science, 1993, 259, 14261428.

28. T. Vossmeyer, G. Reck, B. Schulz, L. Katsikas, H. Weller, J. Am. Chem. Soc., $1995,117,12881-12882$.

29. A. Eichhöfer, P. T. Wood, R. N. Viswanath, R.A. Mole, Chem. Commun., 2008, 1596-1598.

30. S. Behrens, M. Bettenhausen, A.C. Deveson, A. Eichhöfer, D. Fenske, A. Lohde, U. Woggon, Angew. Chem. Int. Ed., 1996, 35, 2215-2218.

31. J. Rockenberger, L. Tröger, A.L. Rogach, M. Tischer, M. Grundmann, A. Eychmüller, H. Weller, J. Chem. Phys., 1998, 108, 7807-7815.

32. N. Zheng, X. Bu, H. Lu, Q. Zhang, P. Feng, J. Am. Chem. Soc., 2005, 127, $11963-$ 11965.

33. A.K. Cheetham, C.N.R. Rao, R.K. Feller, Chem. Commun., 2006, 4780-4795.

34. I. G. Dance, J. Am. Chem. Soc., 1980, 102, 3445-3451.

35. G.A. Casagrande, E.S. Lang, G. Manzoni de Oliveira, M. Hörner, F. Broch, Inorg. Chim. Acta, 2007, 360, 1776-1779; E.S. Lang, B. Tirloni, G. Manzoni de Oliveira, M.A. Villetti, Inorg. Chim. Acta, 2009, 362, 3114-3118.

36. K. S. Anjali, J.J. Vittal, Inorg. Chem. Commun., 2000, 3, 708-710.

37. D. Craig, I. G. Dance, R. Garbutt, Angew. Chem. Int. Ed. Engl, 1986, 25, 165-166.

38. I. G. Dance, R. G. Garbutt, D. C. Craig, M. L. Scudder, Inorg. Chem., 1987, 26, 4057-4064.

39. I. G. Dance, R. G. Garbutt, D. C. Craig, M.L. Scudder, T. D. Bailey, J. Chem. Soc., Chem. Commun., 1987, 1164-1167.

40. I.G. Dance, R.G. Garbutt, M.L. Scudder, Inorg. Chem., 1990, 29, 1571-1575.

41. Q. Zhang, X. Bu, J. Zhang, T. Wu, P. Feng, J. Am. Chem. Soc., 2007, 129, 84128413.

42. Q. Zhang, Z. Lin, X. Bu, T. Wu, P. Feng, Chem. Mater., 2008, 20, 3239-3241.

43. T. Vossmeyer, G. Reck, L. Katsikas, E.T.K. Haupt, B. Schultz, H. Weller, Science, 1995, 267, 1476-1479.

44. Q. Zhang, Y. Liu, X. Bu, T. Wu, P. Feng, Angew. Chem. Int. Ed., 2008, 47, $113-$ 116. 
45. N. Zheng, H. Lu, X. Bu, P. Feng, J. Am. Chem. Soc., 2006, 128, 4528-4529.

46. J. Xie, X. Bu, N. Zheng, P. Feng, Chem. Commun., 2005, 4916-4918.

47. N. Zheng, X. Bu, H. Lu, L. Chen, P. Feng, J. Am. Chem. Soc., 2005, 127, 1499014991.

48. Q. Zhang, X. Bu, Z. Lin, T. Wu, P. Feng, Inorg. Chem., 2008, 47, 9724-9726.

49. N. Zheng, X. Bu, J. Lauda, P. Feng, Chem. Mater., 2006, 18, 4307-4311.

50. C. Xu, Y-G. Han, T. Duan, Q-F Zhang, W-H Leung, Inorg. Chem. Commun., 2009, 12, 1053-1056.

51. X. Jin, K. Tang, S. Jia, Y. Tang, Polyhedron, 1996, 15, 2617-2622.

52. P. Vaqueiro and M. L. Romero, Inorg. Chem., 2009, 48, 810-812.

53. P. Vaqueiro and M. L. Romero, J. Am. Chem. Soc. 2008, 130, 9630-9631.

54. P. Vaqueiro, M. L. Romero, B. C. Rowan and B. S. Richards, Chem.-Eur. J., in press.

55. Q. Zhang, I. Chung, J.I. Jang, J.B. Ketterson, M.G. Kanatzidis, Chem. Mater., 2009, 21, 12-14.

56. N. Zheng, X. Bu, P. Feng, Chem. Commun., 2005, 2805-2807. 
Table 1 Hybrid extended structures based on tetrahedral chalcogenolate clusters.

\begin{tabular}{|c|c|c|c|c|c|}
\hline Compound $^{\mathrm{a}}$ & Synthesis & Cluster & Class & Structure & Ref \\
\hline $\begin{array}{l}{\left[\mathrm{Zn}_{4}(\mathrm{SPh})_{8} \mathrm{ROH}\right]} \\
\mathrm{R}=\mathrm{CH}_{3}, \mathrm{C}_{2} \mathrm{H}_{5}, \mathrm{C}_{3} \mathrm{H}_{7}, \mathrm{C}_{4} \mathrm{H}_{9}\end{array}$ & $\begin{array}{l}\text { Crystallisation } \\
\text { from solution }\end{array}$ & $\mathrm{T} 2$ & $\mathrm{I}^{1} \mathrm{O}^{0}$ & Zig-zag chains & 34 \\
\hline$\left[\mathrm{Hg}_{4}(\mathrm{SePh})_{7} \mathrm{XPy}\right]_{\mathrm{n}}(\mathrm{X}=\mathrm{Cl}, \mathrm{I}, \mathrm{Br})$ & $\begin{array}{l}\text { Crystallisation } \\
\text { from solution }\end{array}$ & $\mathrm{T} 2$ & $\mathrm{I}^{1} \mathrm{O}^{0}$ & Zig-zag chains & 35 \\
\hline$\left[\mathrm{Cd}(\mathrm{SPh})_{2}\right]$ & $\begin{array}{l}\text { Crystallisation } \\
\text { from solution }\end{array}$ & $\mathrm{T} 2$ & $\mathrm{I}^{3} \mathrm{O}^{0}$ & $\begin{array}{c}\text { Cristobalite } \\
\text { (diamond) }\end{array}$ & 37 \\
\hline$\left[\mathrm{Cd}(\mathrm{SePh})_{2}\right]$ & $\begin{array}{l}\text { Crystallisation } \\
\text { from solution }\end{array}$ & $\mathrm{T} 2$ & $\mathrm{I}^{3} \mathrm{O}^{0}$ & $\begin{array}{l}\text { Cristobalite } \\
\text { (diamond) }\end{array}$ & 36 \\
\hline$\left[\mathrm{Cd}(\mathrm{SPhMe}-4)_{2}\right]$ & $\begin{array}{l}\text { Crystallisation } \\
\text { from solution }\end{array}$ & $\mathrm{T} 2$ & $\mathrm{I}^{3} \mathrm{O}^{0}$ & $\mathrm{CrB}_{4}$ & 38 \\
\hline$\left[\mathrm{Cd}_{8}(\mathrm{SPhBr}-4)_{16}(\mathrm{DMF})_{3}\right]$ & $\begin{array}{l}\text { Crystallisation } \\
\text { from solution }\end{array}$ & $\mathrm{T} 2$ & $\mathrm{I}^{2} \mathrm{O}^{0}$ & $\begin{array}{c}\text { Honeycomb-type } \\
\text { layers }\end{array}$ & 39 \\
\hline$\left[\mathrm{Cd}_{8} \mathrm{~S}(\mathrm{SPhMe}-3)_{14}\right]$ & $\begin{array}{l}\text { Crystallisation } \\
\text { from solution }\end{array}$ & P1 & $\mathrm{I}^{3} \mathrm{O}^{0}$ & $\beta$-Quartz & 41 \\
\hline$\left[\mathrm{Cd}_{8} \mathrm{~S}(\mathrm{SPhF}-3)_{12}(\mathrm{SPhF}-3)_{4 / 2}\right]$ & Solvothermal & P1 & $\mathrm{I}^{3} \mathrm{O}^{0}$ & $\alpha$-Quartz & 42 \\
\hline $\begin{array}{l}{\left[\mathrm{Cd}_{8} \mathrm{~S}(\mathrm{SPhMe}-3)_{14}\right]_{2}} \\
{\left[\mathrm{Cd}_{17} \mathrm{~S}_{4}(\mathrm{SPhMe}-3)_{26}\right]}\end{array}$ & Solvothermal & $\mathrm{C} 1, \mathrm{P} 1$ & $\mathrm{I}^{3} \mathrm{O}^{0}$ & Moganite & 41 \\
\hline$\left[\mathrm{Cd}_{17} \mathrm{~S}_{4}\left(\mathrm{SCH}_{2} \mathrm{CH}_{2} \mathrm{OH}\right)_{26}\right]$ & $\begin{array}{l}\text { Crystallisation } \\
\text { from solution }\end{array}$ & $\mathrm{C} 1$ & $\mathrm{I}^{3} \mathrm{O}^{0}$ & Double diamond & 43 \\
\hline$\left[\mathrm{Cd}_{17} \mathrm{~S}_{4}(\mathrm{SPhMe}-4)_{26}\right]$ & Solvothermal & $\mathrm{C} 1$ & $\mathrm{I}^{3} \mathrm{O}^{0}$ & $\beta$-Quartz & 41 \\
\hline $\begin{array}{l}{\left[\left\{\left(\mathrm{NH}_{4}\right)_{2}\left[\mathrm{Cd}_{17} \mathrm{~S}_{4}(\mathrm{SPhMe}-3)_{24}\right.\right.\right.} \\
\left.(\mathrm{SPhMe}-3)_{4 / 2}\right]_{3}\left[\mathrm{Cd}_{17} \mathrm{~S}_{4}(\mathrm{SPhMe}-\right. \\
3)_{24}(\mathrm{SPhMe}-3)_{3 / 2}(\mathrm{SPhMe}- \\
\left.\left.3)]_{4}\right\}_{\mathrm{n}}\right]\end{array}$ & Solvothermal & $\mathrm{C} 1$ & $\mathrm{I}^{3} \mathrm{O}^{0}$ & Boracite & 44 \\
\hline $\begin{array}{l}{\left[\mathrm{M}(\mathrm{phen})_{3}\right]\left[\mathrm{Cd}_{32} \mathrm{~S}_{14}(\mathrm{SPh})_{38}\right]} \\
\mathrm{M}=\mathrm{Fe}, \mathrm{Ru}\end{array}$ & Solvothermal & $\mathrm{C} 2$ & $\mathrm{I}^{3} \mathrm{O}^{0}$ & Double diamond & 45 \\
\hline $\begin{array}{l}{\left[\mathrm{Zn}{ }_{8} \mathrm{~S}(\mathrm{SPh})_{14} \mathrm{~L}_{2}\right]} \\
\mathrm{L}=\mathrm{DPE}, \mathrm{bpp}\end{array}$ & Solvothermal & P1 & $\mathrm{I}^{0} \mathrm{O}^{1}$ & Zig-zag chains & 46 \\
\hline$\left[\mathrm{Cd}_{32} \mathrm{~S}_{14}(\mathrm{SPh})_{36}(\mathrm{bpp})_{2}\right]$ & Solvothermal & $\mathrm{C} 2,1$ & $\mathrm{I}^{0} \mathrm{O}^{1}$ & $\begin{array}{c}\text { Doubly bridged } \\
\text { chains }\end{array}$ & 47 \\
\hline$\left[\mathrm{Cd}_{32} \mathrm{~S}_{14}(\mathrm{SPh})_{38}(\mathrm{bpp})\right]\left[\mathrm{C}_{24} \mathrm{H}_{20} \mathrm{P}\right]_{2}$ & Solvothermal & $\mathrm{C} 2,2$ & $\mathrm{I}^{0} \mathrm{O}^{1}$ & Zig-zag chains & 47 \\
\hline $\begin{array}{l}{\left[\mathrm{Cd}_{17} \mathrm{~S}_{4}(\mathrm{QPh})_{26}(\text { bipy })\right]} \\
\mathrm{Q}=\mathrm{S}, \mathrm{Se}\end{array}$ & Solvothermal & $\mathrm{C} 1$ & $\mathrm{I}^{0} \mathrm{O}^{1}$ & Zig-zag chains & 47 \\
\hline$\left[\mathrm{Cd}_{8} \mathrm{~S}\left(\mathrm{SPh}_{14}\right)(\mathrm{bpp})\right]$ & Solvothermal & $\mathrm{C} 0$ & $\mathrm{I}^{0} \mathrm{O}^{1}$ & Zig-zag chains & 47 \\
\hline$\left\{\left[\mathrm{Cd}_{8} \mathrm{~S}(\mathrm{SPh})_{14}\right]_{2}(\mathrm{TPOM})\right\}_{\mathrm{n}}$ & Solvothermal & $\mathrm{P} 1$ & $\mathrm{I}^{0} \mathrm{O}^{1}$ & Ribbons & 48 \\
\hline$\left\{\left[\mathrm{Cd}_{17} \mathrm{~S}_{4}(\mathrm{SPh})_{26}\right](\mathrm{TPOM})\right\}_{\mathrm{n}}$ & Solvothermal & $\mathrm{C} 1$ & $\mathrm{I}^{0} \mathrm{O}^{1}$ & Zig-zag chains & 48 \\
\hline$\left[\mathrm{Cd}_{32} \mathrm{~S}_{14}(\mathrm{SPh})_{36}(\mathrm{bpp})_{2}\right]$ & Solvothermal & $\mathrm{C} 2,1$ & $\mathrm{I}^{0} \mathrm{O}^{2}$ & $\begin{array}{l}\text { Layers containing } \\
\text { dimeric units }\end{array}$ & 49 \\
\hline$\left[\mathrm{Cd}_{32} \mathrm{~S}_{14}(\mathrm{SPh})_{36}(\mathrm{BPEA})_{2}\right]$ & Solvothermal & $\mathrm{C} 2,1$ & $\mathrm{I}^{0} \mathrm{O}^{2}$ & $\begin{array}{l}\text { Layers containing } \\
\text { dimeric units }\end{array}$ & 49 \\
\hline$\left\{\mathrm{Cd}_{10} \mathrm{Te}_{4}(\mathrm{SPhMe}-4)_{12}(\mathrm{bpp})_{2}\right\}_{\mathrm{n}}$ & Solvothermal & T3 & $\mathrm{I}^{0} \mathrm{O}^{2}$ & $\begin{array}{l}\text { Interpenetrating } \\
\text { square layers }\end{array}$ & 50 \\
\hline $\begin{array}{l}{\left[\mathrm{Cd}_{17} \mathrm{~S}_{4}(\mathrm{SPh})_{24}\left(\mathrm{CH}_{3} \mathrm{OCS}_{2}\right)_{2}\right] \cdot n \mathrm{C}} \\
\mathrm{H}_{3} \mathrm{OH}\end{array}$ & $\begin{array}{l}\text { Crystallisation } \\
\text { from solution }\end{array}$ & $\mathrm{C} 1$ & $\mathrm{I}^{0} \mathrm{O}^{3}$ & Double diamond & 51 \\
\hline
\end{tabular}

a Abbreviations for the ligands: bipy $=4,4$ '-bipyridine; BPEA $=1$,2-bis(4pyridyl)ethane; DPE = 1,2-bis(4-pyridyl)ethylene; bpp =1,3-bis(4-pyridyl)propane; TPOM $=$ tetrakis(4-pyridyloxymethylene) methane; phen $=1,10$-phenanthroline. 
Table 2 Hybrid extended structures based on tetrahedral chalcogenide clusters.

\begin{tabular}{|l|l|l|l|l|l|}
\hline Compound & Synthesis & Cluster & Class & Structure type & Ref \\
\hline$\left[\mathrm{C}_{6} \mathrm{H}_{8} \mathrm{~N}\right]_{2}\left[\mathrm{Ga}_{10} \mathrm{~S}_{16}\left(\mathrm{NC}_{6} \mathrm{H}_{7}\right)_{2}\left(\mathrm{~N}_{2} \mathrm{C}_{12} \mathrm{H}_{12}\right)\right]$ & Solvothermal & $\mathrm{T} 3$ & $\mathrm{I}^{0} \mathrm{O}^{1}$ & Zig-zag chains & 53 \\
\hline$\left[\mathrm{C}_{7} \mathrm{H}_{10} \mathrm{~N}\right]_{2}\left[\mathrm{Ga}_{10} \mathrm{~S}_{16}\left(\mathrm{NC}_{7} \mathrm{H}_{9}\right)\left(\mathrm{N}_{2} \mathrm{C}_{12} \mathrm{H}_{10}\right)_{3 / 2}\right]$ & Solvothermal & $\mathrm{T} 3$ & $\mathrm{I}^{0} \mathrm{O}^{2}$ & $\begin{array}{c}\text { Honeycomb-type } \\
\text { layers }\end{array}$ & 53 \\
\hline$\left\{\left[\mathrm{In}(\text { en })_{3}\right]\left[\mathrm{In}_{5} \mathrm{Te}_{9}(\text { en })_{2}\right] \cdot 0.5 e n\right\}_{n}$ & Solvothermal & $\mathrm{T} 2, \mathrm{~T} 1$ & $\mathrm{I}^{2} \mathrm{O}^{0}$ & Layered & 55 \\
\hline
\end{tabular}




\section{Figure captions}

\begin{tabular}{|c|c|}
\hline Figure 1 & The first three members of the supertetrahedron Tn family. \\
\hline Figure 2 & $\begin{array}{l}\text { (a) The } \mathrm{T} 2\left[\mathrm{Co}_{4}(\mathrm{SPh})_{10}\right]^{2-} \text { cluster; }\left(\text { b) the } \mathrm{T} 3\left[\mathrm{Ga}_{10} \mathrm{~S}_{16}\left(\mathrm{NC}_{7} \mathrm{H}_{9}\right)_{4}\right]^{2-}\right. \\
\text { cluster; and } \quad \text { (c) polyhedral representation of the } \mathrm{T} 2,2 \\
{\left[\mathrm{Cd}_{16}(\mathrm{SePh})_{32}\left(\mathrm{PPh}_{3}\right)_{2}\right] \text { cluster. }}\end{array}$ \\
\hline Figure 3 & $\begin{array}{l}\text { The first two members of the pentasupertetrahedral } \mathrm{Pn} \text { family. A } \\
\text { polyhedral representation is used for the central antisupertetrahedral } \\
\text { cluster. }\end{array}$ \\
\hline Figure 4 & The first two members of the capped Cn family. \\
\hline Figure 5 & $\begin{array}{l}\text { The zig-zag chains of T2 supertetrahedral clusters found in } \\
{\left[\mathrm{Zn}_{4}(\mathrm{SPh})_{8} \mathrm{CH}_{3} \mathrm{OH}\right] \text {. }}\end{array}$ \\
\hline Figure 6 & $\begin{array}{l}\text { Polyhedral representation of the crystal structure of }(\mathrm{a})\left[\mathrm{Cd}(\mathrm{SPh})_{2}\right] \\
\text { viewed along }[100] \text { and }(\mathrm{b})\left[\mathrm{Cd}(\mathrm{SPhMe}-4)_{2}\right] \text { along }[010] \text {. The carbons } \\
\text { in the thiolate ligands have been omitted for clarity. }\end{array}$ \\
\hline Figure 7 & $\begin{array}{l}\text { Polyhedral representation of the crystal structure of (a) } \\
{\left[\mathrm{Cd}_{17} \mathrm{~S}_{4}(\mathrm{SPhMe}-4)_{26}\right] \text { viewed along }[001] \text { and (b) }\left[\mathrm{Cd}_{8} \mathrm{~S}(\mathrm{SPhMe}-\right.} \\
\left.3)_{14}\right]_{2}\left[\mathrm{Cd}_{17} \mathrm{~S}_{4}(\mathrm{SPhMe}-3)_{26}\right] \text { along [001]. The carbons in the thiolate } \\
\text { groups have been omitted for clarity. }\end{array}$ \\
\hline Figure 8 & $\begin{array}{l}\text { Polyhedral representation of the hybrid chains found in (a) } \\
{\left[\mathrm{Zn}_{8} \mathrm{~S}(\mathrm{SPh})_{14}(\mathrm{DPE})_{2}\right] ;} \\
\left\{\left[\mathrm{Cd}_{17} \mathrm{~S}_{4}(\mathrm{SPh})_{26}\right] \mathrm{TPOM}\right\}_{\mathrm{n}} \text { and }(\mathrm{d})\left\{\left[\mathrm{Cd}_{8} \mathrm{~S}(\mathrm{SPh})_{14}\right]_{2} \mathrm{TPOM}\right\}_{\mathrm{n}} \text {. In (b) and } \\
\text { (d), the carbons in the thiolate groups have been omitted for clarity. }\end{array}$ \\
\hline Figure 9 & $\begin{array}{l}\text { Polyhedral representation of a layer of }\left[\mathrm{Cd}_{32} \mathrm{~S}_{14}(\mathrm{SPh})_{36}(\mathrm{bpp})_{2}\right] \text { along } \\
{[101] \text {. The carbons in the thiolate groups have been omitted for clarity. }}\end{array}$ \\
\hline Figure 10 & $\begin{array}{l}\text { View of the linkage through a } \mathrm{CH}_{3} \mathrm{OCS}_{2}^{-} \text {ligand found in } \\
{\left[\mathrm{Cd}_{17} \mathrm{~S}_{4}(\mathrm{SPh})_{24}\left(\mathrm{CH}_{3} \mathrm{OCS}_{2}\right)_{4 / 2}\right] \cdot n \mathrm{CH}_{3} \mathrm{OH} \text {. }}\end{array}$ \\
\hline Figure 11 & 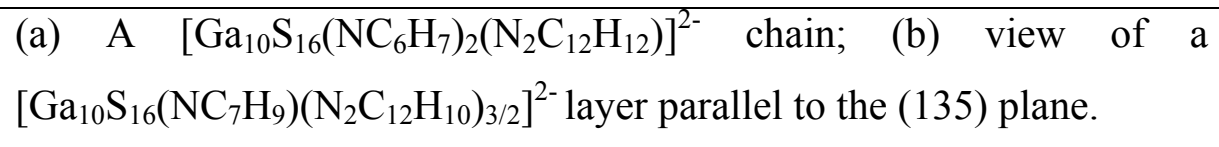 \\
\hline Figure 12 & $\begin{array}{l}\text { View of a single } \\
\left\{\left[\operatorname{In}(e n)_{3}\right]\left[\operatorname{In}_{5} \mathrm{Te}_{9}(\text { en })_{2}\right] \cdot 0.5 e n\right\}_{n}\end{array}$ \\
\hline
\end{tabular}


Table of contents

Text for the Graphical Abstract

Advances on the use of chalcogenide tetrahedral clusters as building blocks for the design of extended inorganic hybrids and coordination polymers are reviewed. These materials offer the potential of integrating porosity with optical properties. 


\section{Biography}

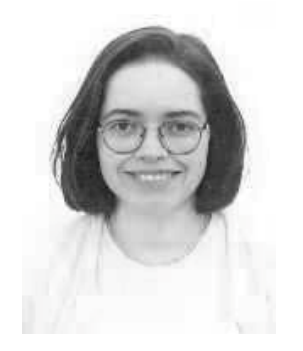

Paz Vaqueiro is a lecturer in Inorganic Materials Chemistry. She completed her PhD on magnetic nanoparticles at the University of Santiago de Compostela, Spain (1997). Following post-doctoral work at Heriot-Watt University (Edinburgh, UK), she held an Advanced Research Fellowship at the same institution (2004-08). Her research interests lie in the field of solid-state materials, with particular emphasis on the exploratory synthesis of complex chalcogenides. Her current research interests include the design of novel high-performance thermoelectric materials and the synthesis of microporous semiconductors based on gallium-sulphide frameworks. 


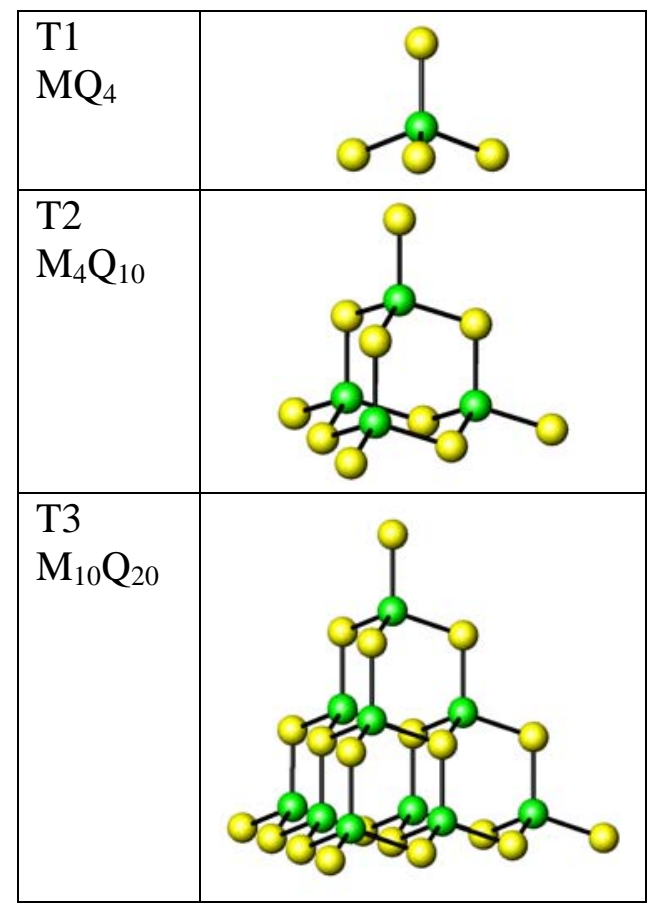

Figure 1 

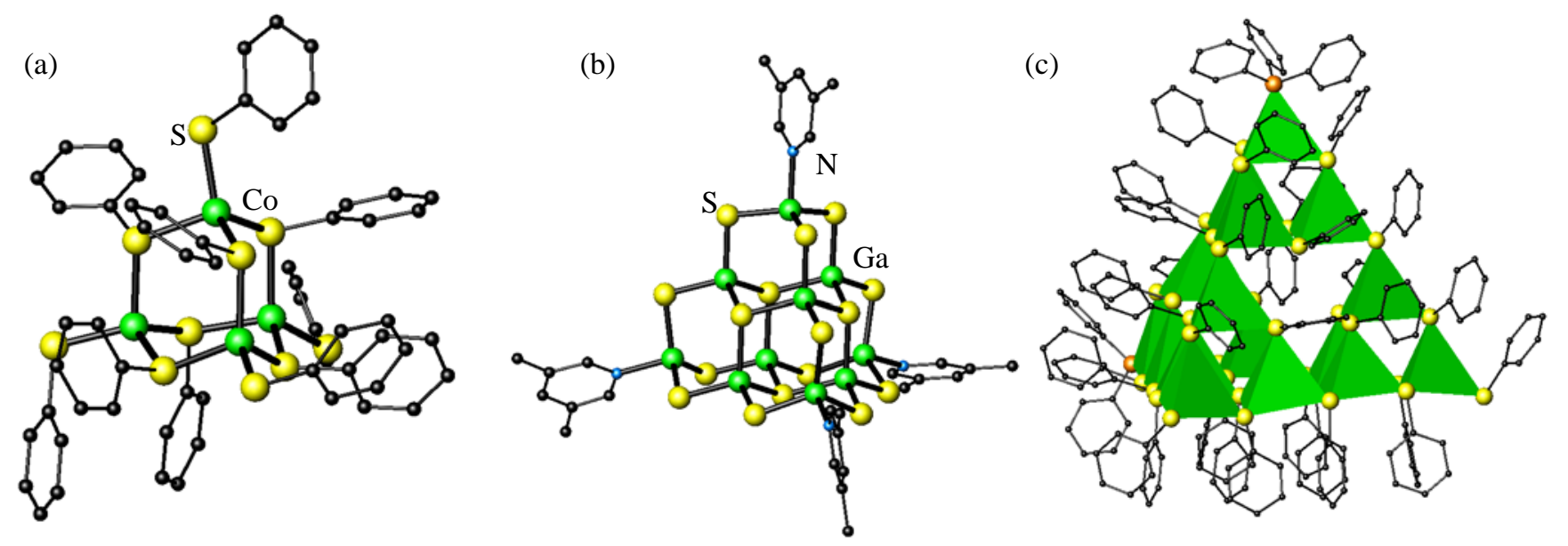

Figure 2 


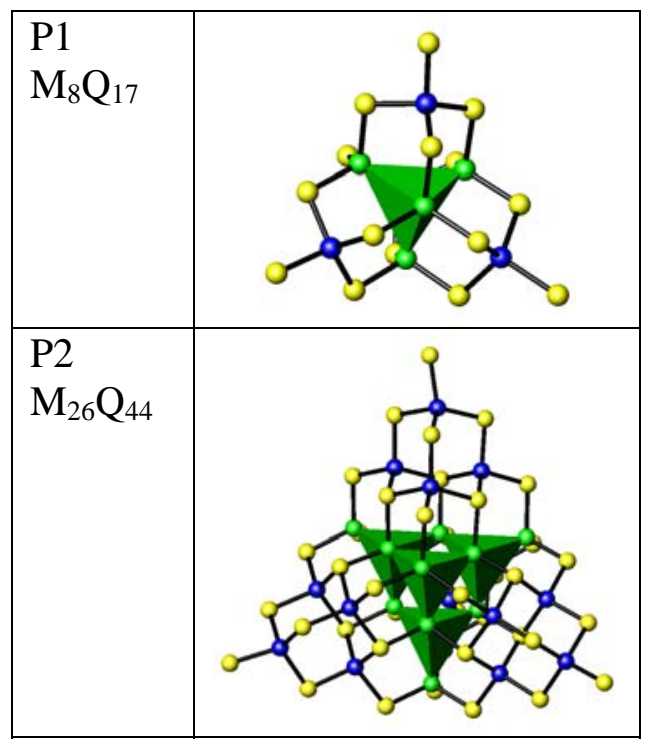

Figure 3 


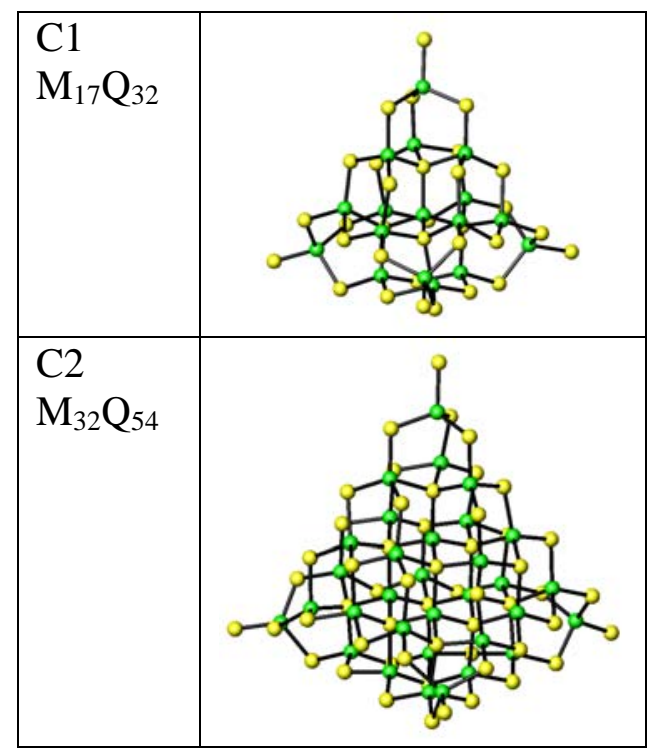

Figure 4 


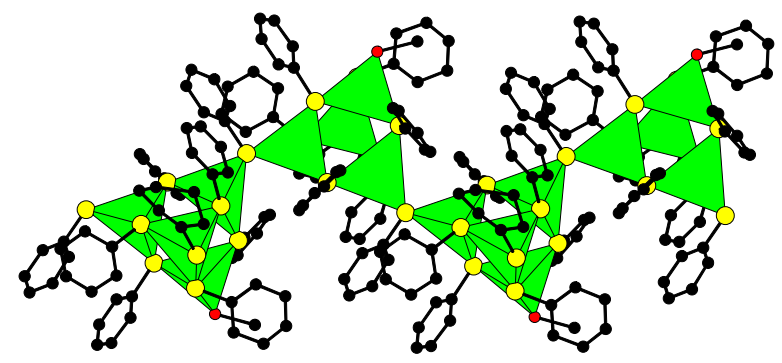

Figure 5 
(a)
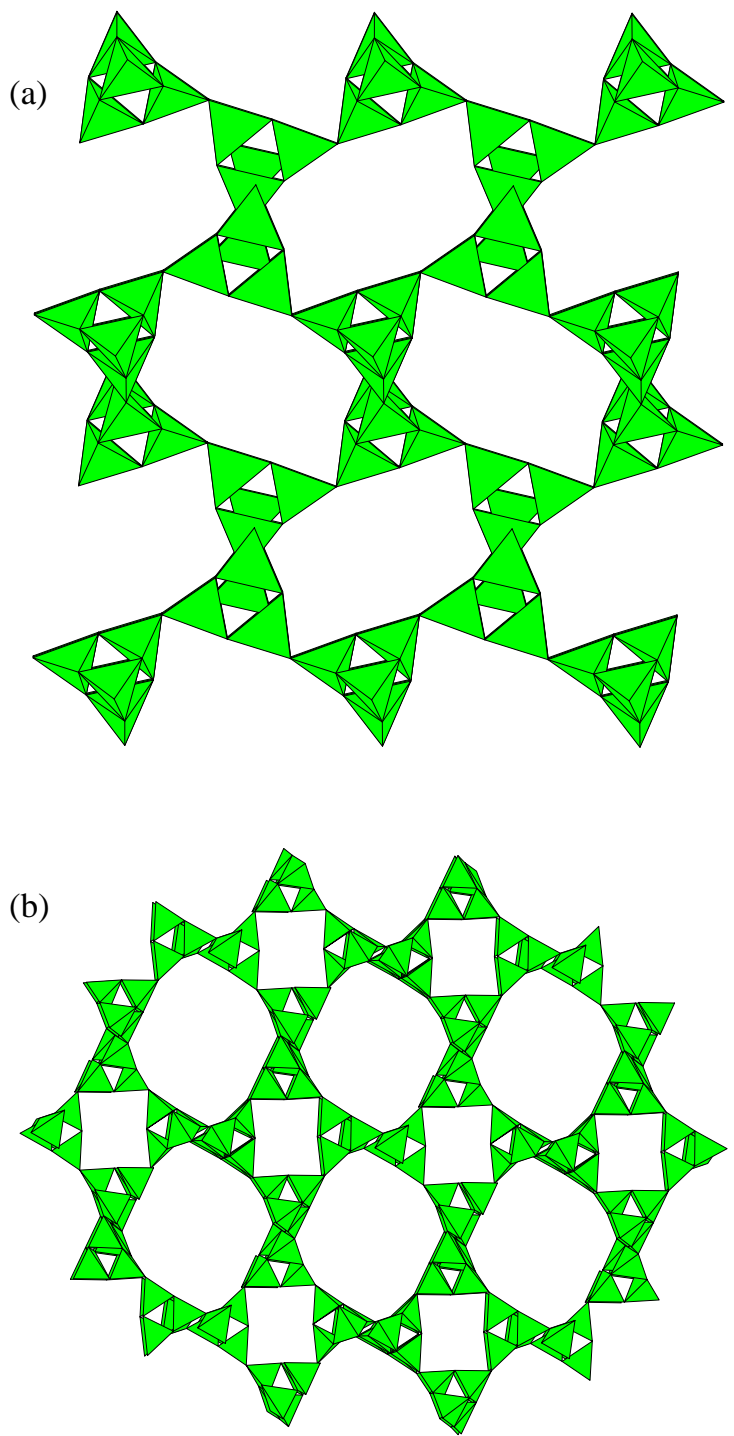

Figure 6 
(a)

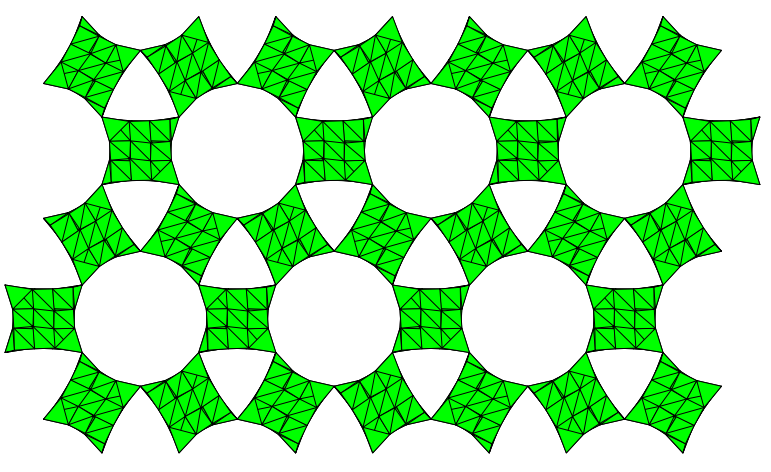

(b)

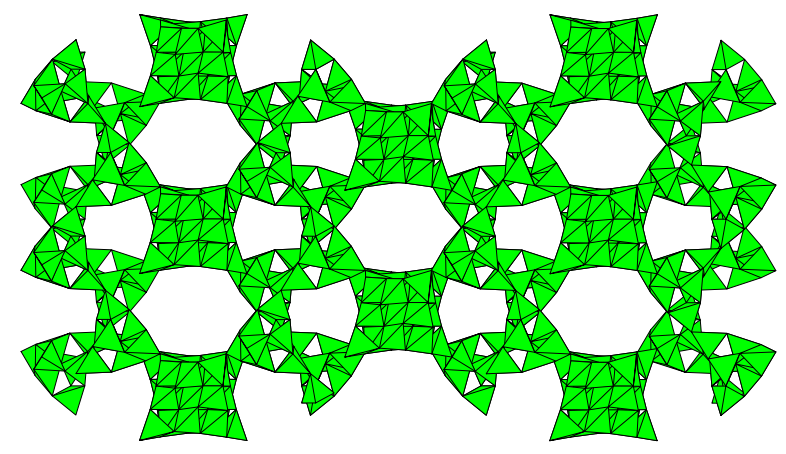

Figure 7 
(a)

(c)

(b)

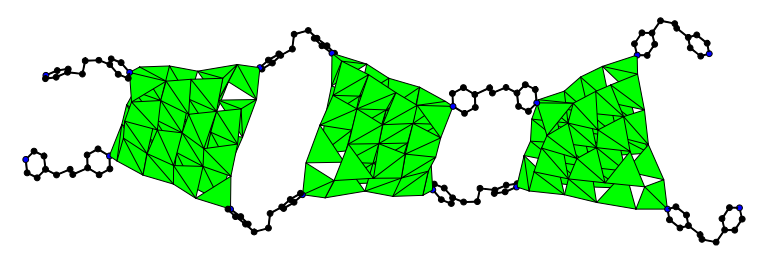

(d)

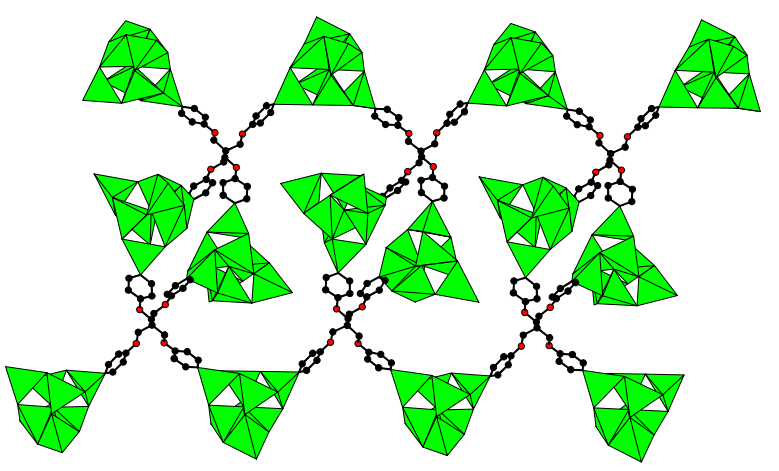

Figure 8 


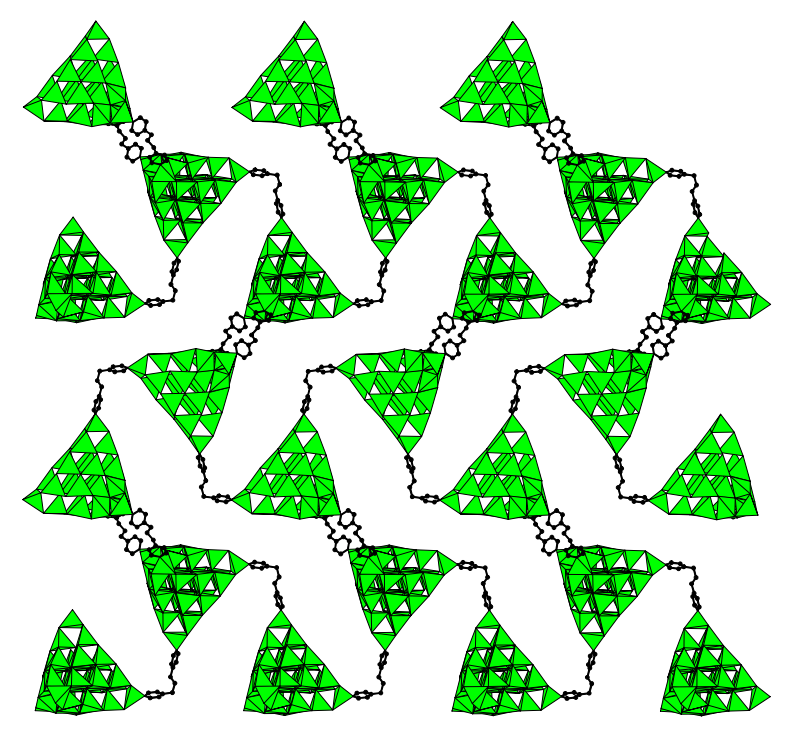

Figure 9 


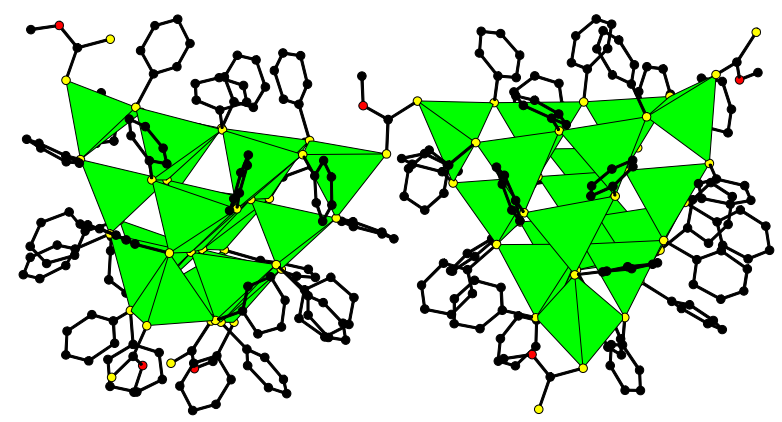

Figure 10 
(a)

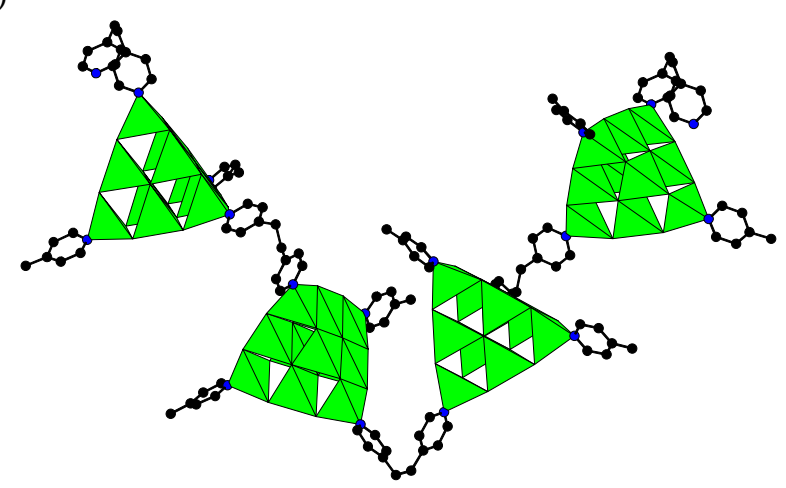

(b)

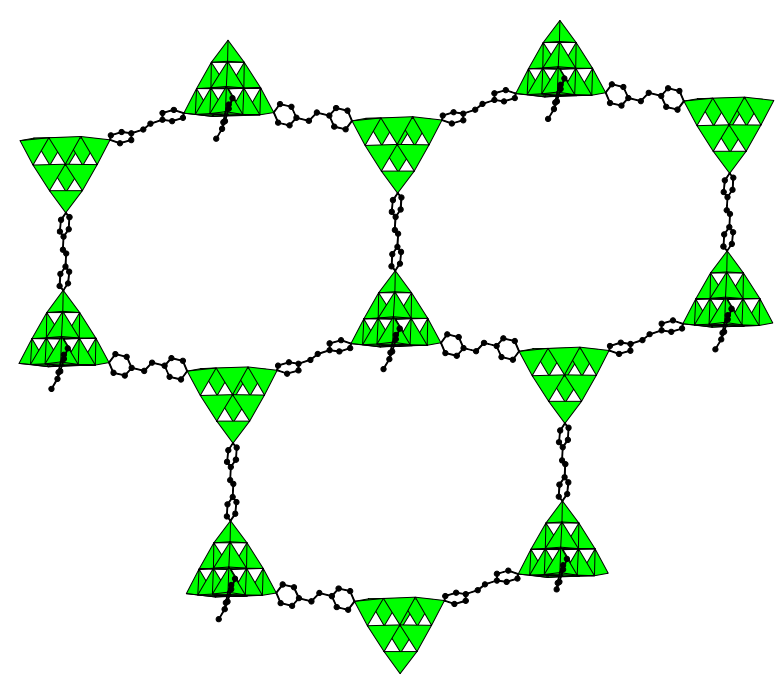

Figure 11 


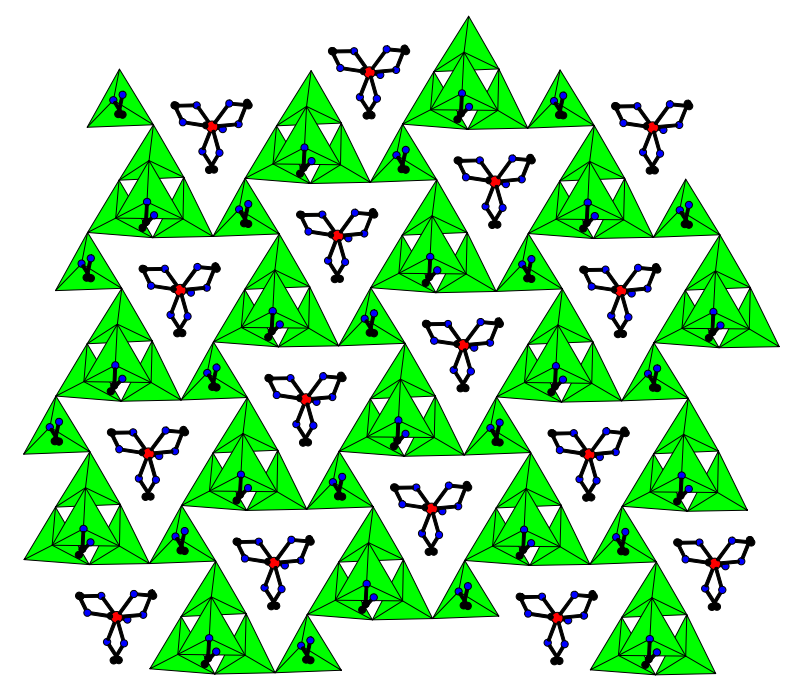

Figure 12 


\section{Table of contents}

Advances on the use of chalcogenide tetrahedral clusters as building blocks for the design of extended inorganic hybrids and coordination polymers are reviewed. These materials offer the potential of integrating porosity with electronic or optical properties. 


\section{Biography}

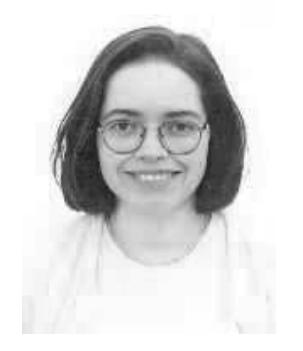

Paz Vaqueiro is a lecturer in Inorganic Materials Chemistry. She completed her PhD on magnetic nanoparticles at the University of Santiago de Compostela, Spain (1997). Following post-doctoral work at Heriot-Watt University (Edinburgh, UK), she held an Advanced Research Fellowship at the same institution (2004-08). Her research interests lie in the field of solid-state materials, with particular emphasis on the exploratory synthesis of complex chalcogenides. Her current research interests include the design of novel high-performance thermoelectric materials and the synthesis of microporous semiconductors based on gallium-sulphide frameworks. 